\title{
Chronic venous insufficiency - epidemiology, classification and clinical picture. Diagnostic and therapeutic recommendations of the Polish Dermatological Society. Part I
}

\author{
Przewlekła niewydolność żylna - epidemiologia, klasyfikacja i obraz kliniczny. \\ Rekomendacje diagnostyczno-terapeutyczne Polskiego Towarzystwa \\ Dermatologicznego. Część I
}

Joanna Narbutt', Monika Bowszyc-Dmochowska², Monika Kapińska-Mrowiecka³, Andrzej Kaszuba', Dorota Krasowska ${ }^{4}$, Beata Kręcisz ${ }^{5,6}$, Aleksandra Lesiak', Anna Lis-Święty ${ }^{7}$ Joanna Maj', Roman J. Nowicki', Witold Owczarek ${ }^{10}$, Waldemar Placek ${ }^{\prime \prime}$, Adam Reich ${ }^{12}$, Lidia Rudnicka'13

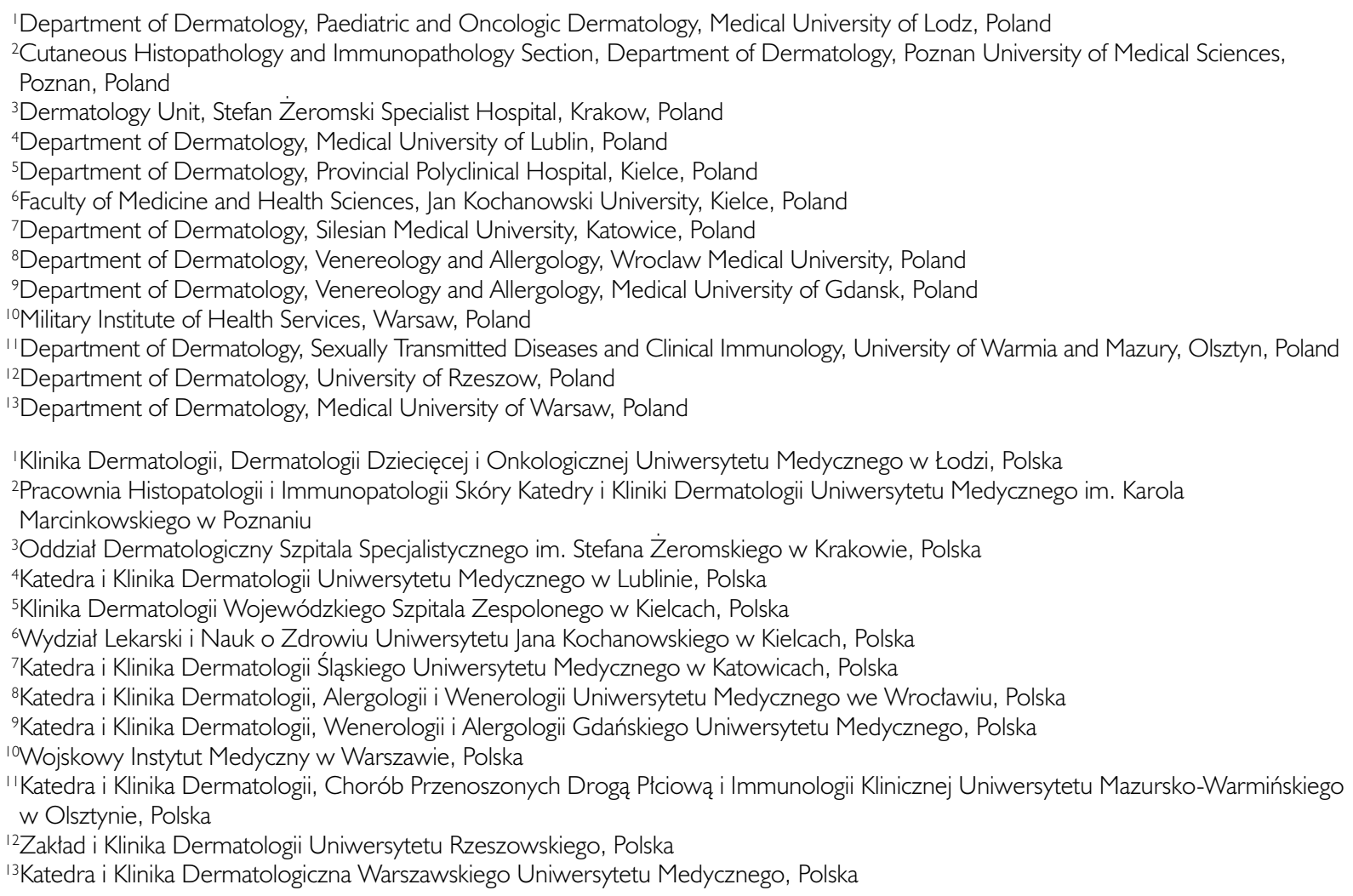

CORRESPONDING AUTHOR/ ADRES DO KORESPONDENCJI: prof. dr hab. n. med. Joanna Narbutt Klinika Dermatologii, Dermatologii Dziecięcej i Onkologicznej

\begin{abstract}
Chronic venous insufficiency is an important clinical problem in daily dermatological practice. The disease is caused by impaired function of the venous system in the lower limbs and affects approximately $60 \%$ of the adult population. The article discusses the key epidemiological factors of chronic venous insufficiency, the updated classification and the clinical features of skin lesions developing in the course of the disease.
\end{abstract}




\section{STRESZCZENIE}

Uniwersytet Medyczny w Łodzi

ul. Krzemieniecka 5

94-017 Łódź, Polska

tel.: +48603756804

e-mail: joanna.narbutt@umed.lodz.pl
Przewlekła niewydolność żylna stanowi istotny problem kliniczny w codziennej praktyce dermatologicznej. Choroba spowodowana jest nieprawidłowym działaniem układu żylnego kończyn dolnych i dotyczy około $60 \%$ dorosłych. W artykule przedstawiono najważniejsze czynniki epidemiologiczne przewlekłej niewydolności żylnej, obowiązującą klasyfikację oraz obraz kliniczny zmian skórnych w jej przebiegu.

Key words: chronic venous insufficiency, epidemiology, classification, clinical picture.

Słowa kluczowe: przewlekła niewydolność żylna, epidemiologia, klasyfikacja, obraz kliniczny.

\section{INTRODUCTION}

Chronic venous disease and chronic venous insufficiency are broad terms referring to diverse clinical symptoms.

In a wide sense, chronic venous disease comprises all clinical manifestations associated with venous disorders of the lower limbs which have a tendency to progress. The mildest forms, which do not affect the quality of life of patients, include minor lesions such as reticular veins and telangiectasias. In contrast, chronic venous insufficiency refers to advanced lesions including edema, skin abnormalities (eczema, pigmentation, induration) and venous ulcers which represent the most severe clinical form and may affect very extensive areas, impairing the patients' normal social and professional functioning.

Chronic venous insufficiency thus encompasses all conditions resulting from pathological, biochemical and immune abnormalities in the venous bed and microcirculation which develop gradually because of disturbed blood outflow from the lower limb veins, venous valve insufficiency and the resulting venous hypertension. In recent years, attention has been drawn to the role of inflammation in the development of clinical symptoms of chronic venous insufficiency.

Venous insufficiency results from the malfunctioning of the venous system of the lower limbs which is most often associated with venous valve insufficiency and may involve superficial or deep veins or both venous systems concurrently. Pathogenetically chronic venous insufficiency refers to all clinical conditions involving difficulties with the outflow of venous blood and elevated venous resting pressure.

Chronic venous insufficiency is treated by doctors of many medical specialties: general practitioners, internists, angiologists, dermatologists, and general and vascular surgeons. In the scope of procedural methods, surgical interventions are performed to eliminate

\section{WPROWADZENIE}

Przewlekła choroba żylna i przewlekła niewydolność żylna to rozległe pojęcia obejmujące różne objawy kliniczne.

W szerokim ujęciu mianem przewlekłej choroby żylnej określa się wszystkie objawy kliniczne związane z chorobami żył kończyn dolnych, które mają tendencję do progresji. Do najłagodniejszych form, niewpływających na jakość życia pacjentów, zalicza się niewielkie zmiany w postaci żył siateczkowatych i teleangiektazji. Termin przewlekła niewydolność żylna odnosi się natomiast do zmian zaawansowanych, takich jak obrzęki, zmiany dermatologiczne (wyprysk, przebarwienia, stwardnienia) oraz owrzodzenia żylne, które są najcięższą postacią kliniczną, mogą obejmować bardzo dużą powierzchnię, uniemożliwiając chorym prawidłowe funkcjonowanie społeczne i zawodowe.

Przewlekła niewydolność żylna stanowi więc zespół zmian chorobowych będących wynikiem zmian patologicznych, biochemicznych, immunologicznych w łożysku żylnym i mikrokrążeniu, powstających stopniowo wskutek zaburzenia odpływu krwi z żył kończyny dolnej, niewydolności ich zastawek i rozwijającego się w efekcie nadciśnienia żylnego. Ostatnio zwraca się uwagę na rolę zapalenia w rozwoju objawów klinicznych przewlekłej niewydolności żylnej.

Niewydolność żylna spowodowana jest nieprawidłowym działaniem układu żylnego kończyn dolnych, co wiąże się najczęściej z niewydolnością zastawek żylnych i może dotyczyć układu żył powierzchownych, głębokich lub obu jednocześnie. Patogenetycznie przewlekłą niewydolnością żylną nazywa się wszystkie stany kliniczne przebiegające $\mathrm{z}$ utrudnieniem odpływu krwi żylnej i podwyższeniem ciśnienia spoczynkowego w naczyniach żylnych.

Leczeniem przewlekłej niewydolności żylnej zajmują się lekarze wielu specjalności, m.in. lekarze rodzinni, interniści, angiolodzy, dermatolodzy oraz chirurdzy 
the cause of clinical changes. The treatment of early clinical symptoms by using pharmacotherapy and compression therapy should be in the scope of practice of all the medical specialties enumerated above. The treatment of ulcers usually falls within the competence of dermatologists and/or vascular surgeons. This study focuses on epidemiological issues and the clinical picture of chronic venous insufficiency. The surgical methods and the topical management of ulcers with the use of dressings are not discussed [1].

\section{EPIDEMIOLOGY}

The prevalence of chronic venous insufficiency in the adult population is estimated at approximately $60 \%$, and it is markedly higher in highly developed countries [2]. Regardless of the clinical form, the disease has a significant negative impact on the activities of daily living and the quality of life of patients [3,4].

Epidemiological studies on chronic venous insufficiency are difficult, since different stages of the disease should be considered separately. The most common are, indisputably, telangiectasias and reticular veins. The problem affects more than half of men and nearly $65 \%$ of women. In Western Europe varicose veins occur in $25-33 \%$ of women and $10-20 \%$ of men, and the prevalence of the condition rises with age, from $3 \%$ in men and $20 \%$ in women in the third decade of life to $40 \%$ and $50 \%$, respectively, over the age of 70 years. Edema is a relatively common problem in patients with varicose veins of the lower limbs. The problem affects about $10 \%$ of men and $20 \%$ of women. Trophic skin lesions secondary to chronic venous insufficiency are more common in women, particularly at an elderly age. The most significant clinical problem is associated with active venous shin ulcers which occur in the adult population in Western European countries at an estimated prevalence of $0.3 \%$ [1].

There are many risk factors for the development of pathologies in the course of chronic venous insufficiency. They include, primarily, age, sex, obesity, positive family history and ethnicity. The age of the patient has been recognized as the most important risk factor, which has been confirmed by a number of epidemiological studies [5]. It is widely recognized that women are more predisposed to the development of varicose veins and edema of the lower limbs, though some epidemiological studies (Edinburgh Vein Study) have failed to demonstrate this correlation [6]. Similarly, no relationship has been found between lower leg varicose veins and oral hormonal contraception, while the number of pregnancies represents an important risk factor [6-8]. Undoubtedly, an important element contributing to the development of pathologies and clinical symptoms of chronic venous insufficiency is obesity, especially body mass index ogólni i naczyniowi. W zakresie specjalności zabiegowych wykonuje się interwencje chirurgiczne usuwające przyczynę powstawania zmian klinicznych. Leczenie pierwszych objawów klinicznych poprzez stosowanie farmakoterapii i kompresjoterapii powinno znajdować się w zakresie działań wszystkich powyższych specjalności. Terapia owrzodzeń zazwyczaj pozostaje w kompetencjach dermatologów i/lub chirurgów naczyniowych. W niniejszym opracowaniu skupiono się na zagadnieniach epidemiologicznych oraz obrazie klinicznym przewlekłej niewydolności żylnej. Nie zostały omówione metody chirurgiczne ani miejscowe leczenie owrzodzeń z zastosowaniem opatrunków [1].

\section{EPIDEMIOLOGIA}

Częstość występowania przewlekłej niewydolności żylnej w populacji dorosłej oceniono na ok. $60 \%$, przy czym zdecydowanie częściej występuje ona w krajach wysoko rozwiniętych [2]. Niezależnie od postaci klinicznej, choroba istotnie negatywnie wpływa na wykonywanie codziennych obowiązków i jakość życia chorych [3, 4].

Przeprowadzenie badań epidemiologicznych dotyczących przewlekłej niewydolności żylnej jest trudne, gdyż należy odrębnie rozpatrywać poszczególne etapy choroby. Najczęściej występują teleangiektazje i żyły siateczkowate. Problem ten dotyczy ponad połowy mężczyzn i blisko 65\% kobiet. Żylaki w krajach Europy Zachodniej występują u 25-33\% kobiet oraz 10-20\% mężczyzn i częstość ich występowania wzrasta z wiekiem - od 3\% u mężczyzn i 20\% u kobiet w trzeciej dekadzie życia do odpowiednio 40\% i 50\% po 70. roku życia. Stosunkowo często obserwuje się obrzęki u osób z żylakami kończyn dolnych, problem ten dotyczy ok. 10\% mężczyzn i 20\% kobiet. Zmiany troficzne skóry rozwijające się na tle przewlekłej niewydolności żylnej częściej występują u kobiet, zwłaszcza w starszym wieku. Największy problem kliniczny stanowią czynne owrzodzenia żylne goleni, których częstość w dorosłej populacji krajów Europy Zachodniej szacuje się na ok. 0,3\% [1].

Istnieje wiele czynników ryzyka rozwoju patologii w przebiegu przewlekłej niewydolności żylnej. Wśród nich wymienia się przede wszystkim wiek, płeć, otyłość, rodzinne występowanie oraz rasę. Wiek pacjenta uznano za najważniejszy czynnik ryzyka, co zostało potwierdzone w wielu badaniach epidemiologicznych [5]. Przyjmuje się powszechnie, że płeć żeńska bardziej predysponuje do rozwoju żylaków kończyn dolnych i obrzęków, jednak w niektórych badaniach epidemiologicznych (Edinburgh Vein Study) nie potwierdzono takiej zależności [6]. Nie stwierdzono związku między żylakami podudzi a stosowaniem doustnej antykoncepcji hormonalnej, natomiast istotnym czynnikiem ryzyka jest liczba ciąż 
(BMI) above $30 \mathrm{~kg} / \mathrm{m}^{2}$, both in women and in men. An interesting observation is that BMI $>40 \mathrm{~kg} / \mathrm{m}^{2}$ promotes the emergence of clinical symptoms of chronic venous insufficiency even in the absence of anatomical changes in the venous system. Consequently, obesity in itself is a pathogenetic factor of venous insufficiency. In some studies the BMI value of $25 \mathrm{~kg} / \mathrm{m}^{2}$ has been considered as a threshold level conducive to the development of chronic venous insufficiency $[9,10]$. Also, a clear correlation has been found between the risk of developing chronic venous insufficiency symptoms and the family history of the disease. This applies in particular to cases with a severe course requiring hospital treatment. Despite research in this field, the genetic background underlying the development of the disease has not been clearly identified yet $[11,12]$.

\section{CHRONIC VENOUS INSUFFICIENCY AND THE QUALITY OF LIFE}

The quality of life of patients definitely depends on the severity of symptoms caused by chronic venous insufficiency. Patients with telangiectasias experience mainly a cosmetic defect associated with the presence of lesions, which occasionally discourages them from practicing sports or requires changes to the style of dressing. Patients with greater severity of symptoms report pain and discomfort, edema, feeling of heavy legs, muscle cramps, pruritus, paresthesia and sleep impairment. The complaints result in the loss of physical activity as well as psychological problems, social functioning disorders and impaired self-perception of one's health status [3, 4].

\section{CLINICAL SYMPTOMS OF CHRONIC VENOUS INSUFFICIENCY AND CEAP CLASSIFICATION}

Symptoms of chronic venous insufficiency are very diverse, however regardless of the severity of the disorder they cause subjective and objective complaints. Patients report the feeling of "heavy legs", tenderness and burning sensation, itchy skin and leg cramps, especially at night. The complaints exacerbate after remaining in the standing position for a long time and at the end of the day, and may subside slightly after physical exercise and resting with elevation of the lower limbs [13-15]. Subsequent stages of the disease involve varicose veins, chronic edema, skin pigmentation and induration, and ulcers.

\section{CEAP classification}

The CEAP classification was proposed in 1994 and revised in 2004. Since then, it has provided a basis for the differentiation of symptoms of chronic
[6-8]. Istotnym elementem sprzyjającym rozwojowi patologii oraz objawom klinicznym przewlekłej niewydolności żylnej jest otyłość, zwłaszcza wskaźnik masy ciała (body mass index - BMI) powyżej $30 \mathrm{~kg} / \mathrm{m}^{2}$. Dotyczy to zarówno kobiet, jak i mężczyzn. Interesująca jest obserwacja, że BMI > $40 \mathrm{~kg} / \mathrm{m}^{2}$ sprzyja objawom klinicznym przewlekłej niewydolności żylnej nawet przy braku zmian anatomicznych w układzie żylnym, co oznacza, że sama otyłość jest czynnikiem patogenetycznym niewydolności żylnej. W niektórych badaniach za progowy wskaźnik BMI sprzyjający rozwojowi przewlekłej niewydolności żylnej uznano wartość $25 \mathrm{~kg} / \mathrm{m}^{2}[9,10]$. Stwierdzono również wyraźny związek między ryzykiem rozwoju objawów przewlekłej niewydolności żylnej a rodzinnym występowaniem choroby. Dotyczy to zwłaszcza przypadków o ciężkim przebiegu, wymagających leczenia szpitalnego. Pomimo prowadzonych badań nie określono dotąd jednoznacznie podłoża genetycznego warunkującego rozwój choroby $[11,12]$.

\section{PRZEWLEKŁA NIEWYDOLNOŚĆ ŻYLNA A JAKOŚĆ ŻYCIA}

Jakość życia pacjentów zależy od nasilenia objawów przewlekłej niewydolności żylnej. Teleangiektazje są traktowane przez pacjentów przede wszystkim jako defekt kosmetyczny, które niekiedy zniechęcają ich do uprawiania sportu lub skłaniają do zmiany sposobu ubierania. Przy większym nasileniu objawów chorobowych pacjenci zgłaszają ból i dyskomfort, obrzęk, uczucie ciężkości nóg, skurcze mięśni, świąd, parestezje i pogorszenie jakości snu. Dolegliwości te powodują utratę aktywności fizycznej, problemy natury psychologicznej, zaburzenie kontaktów społecznych i postrzegania własnego zdrowia [3, 4].

\section{OBJAWY KLINICZNE PRZEWLEKŁEJ NIEWYDOLNOŚCI ŻYLNEJ I KLASYFIKACJA CEAP}

Objawy przewlekłej niewydolności żylnej są bardzo różnorodne, jednak niezależnie od nasilenia stanowią przyczynę dolegliwości podmiotowych i przedmiotowych. Pacjenci zgłaszają uczucie ciężkości nóg, bolesność i pieczenie oraz świąd skóry, a także skurcze, szczególnie nocne. Dolegliwości nasilają się po długim utrzymywaniu pozycji stojącej i wieczorem, mogą nieco ustąpić po wysiłku fizycznym i odpoczynku z uniesieniem kończyn dolnych [13-15]. W kolejnych etapach choroby widoczne są żylaki, utrwalony obrzęk, przebarwienia i stwardnienia skóry oraz owrzodzenia.

\section{Klasyfikacja CEAP}

W 1994 r. powstała klasyfikacja CEAP, która została zrewidowana w 2004 r. i do tej pory stanowi 
venous insufficiency based on clinical $(C)$, etiological (E), anatomical (A) and pathophysiological (P) features [5].

The current version of the CEAP classification is presented in table 1.

Clinical classification (C)

The higher the number, the more clinical symptoms are found, however even if the number is high, the patient may not report any symptoms. It needs to be stressed that telangiectasias arbitrarily refer to dilatations of intradermal venules to approximately $1 \mathrm{~mm}$, and reticular veins are impalpable dilatations of subcutaneous veins to approximately $4 \mathrm{~mm}$. Varicose veins are palpable subcutaneous veins, usually measuring more than $4 \mathrm{~mm}$ in diameter.

\section{Etiological classification (E)}

Congenital lesions are present from birth. Among them, Klippel-Trenaunay syndrome, Parkes-Weber syndrome or congenital venous malformations can be mentioned. Primary lesions are the cause of in-

Table I. CEAP classification

\begin{tabular}{l} 
Clinical classification (C) \\
C0 - no clinical signs \\
\hline $\mathrm{Cl}$ - telangiectasias, reticular veins \\
\hline $\mathrm{C} 2$ - varicose veins \\
\hline $\mathrm{C} 3$ - edema \\
\hline C4a - pigmentation, eczema \\
\hline C4b - lipodermatosclerosis, atrophie blanche lesions \\
\hline C5 - skin lesions including healed venous ulcers \\
\hline C6 - skin lesions including active ulcers on the lower legs \\
\hline A - asymptomatic \\
\hline S - symptoms: pain, hypersensitivity, burning sensation on the \\
skin, feeling of heavy legs, muscle cramps \\
Etiological classification (E) \\
Ec - congenital lesions \\
\hline Ep - primary lesions in the venous system without evident \\
cause \\
\hline Es - secondary lesions, e.g. post-traumatic, post-thrombotic \\
\hline En - no etiology identified \\
Anatomical classification (A) \\
As - superficial veins \\
\hline Ad - deep veins \\
\hline Ap - perforator veins \\
\hline An - no identification \\
Pathophysiological classification (P) \\
Pr - reflux \\
\hline Po - obstruction \\
\hline Pr,o - reflux and obstruction \\
\hline Pn - no identification \\
\hline
\end{tabular}

podstawę podziału objawów przewlekłej niewydolności żylnej opartego na cechach klinicznych (C), etiologicznych (E), anatomicznych (A) i patofizjologicznych $(\mathrm{P})$ [5].

W tabeli 1 przedstawiono obowiązującą klasyfikację CEAP.

\section{Klasyfikacja kliniczna (C)}

Im wyższa liczba w klasyfikacji klinicznej, tym występuje więcej objawów klinicznych, jednak nawet przy wysokiej numeracji pacjent może nie zgłaszać objawów podmiotowych. Należy pamiętać, że teleangiektazje to rozszerzenie śródskórnych żyłek do średnicy ok. $1 \mathrm{~mm}$, natomiast żyłami siateczkowatymi nazywa się niewyczuwalne rozszerzenia żył podskórnych od ok. $1 \mathrm{~mm}$ do ok. $4 \mathrm{~mm}$. Żylaki to palpacyjnie wyczuwalne podskórne żyły, zwykle o średnicy większej niż $4 \mathrm{~mm}$.

\section{Klasyfikacja etiologiczna (E)}

Zmiany wrodzone są obecne od urodzenia. Wśród tych zmian wymienia się m.in. zespół Klip-

Tabela I. Klasyfikacja CEAP

\begin{tabular}{l} 
Klasyfikacja kliniczna (C) \\
C0 - brak objawów klinicznych \\
\hline Cl - teleangiektazje, żyły siatkowate \\
\hline C2 - żylaki \\
\hline C3 - obrzęk \\
\hline C4a - przebarwienia, wyprysk \\
\hline C4b - stwardnienia, zmiany typu atrophie blanche \\
\hline C5 - zmiany skórne, w tym wygojone owrzodzenia żylne \\
\hline C6 - zmiany skórne, w tym aktywne owrzodzenie podudzi \\
\hline A - asymptomatyczne \\
\hline S - występują objawy: ból, nadwrażliwość, pieczenie skóry, \\
uczucie ciężkości nóg, skurcze mięśni
\end{tabular}

\section{Klasyfikacja etiologiczna $(E)$}

Ec - zmiany wrodzone

Ep - zmiany pierwotne układu żylnego bez ewidentnej przyczyny

S - zmiany wtórne, np. pourazowe, pozakrzepowe

En - przyczyna nieznana

\section{Klasyfikacja anatomiczna (A)}

As - żyły powierzchniowe

Ad - żyły głębokie

Ap - żyły przeszywające

An - brak identyfikacji

Klasyfikacja patofizjologiczna (P)

Pr - refluks

Po - niedrożność żył

Pr,o - refluks i zaburzenia drożności

$\mathrm{Pn}$ - brak identyfikacji 
sufficiency of the venous system, typically developing at the junction of the superficial and deep vein systems, and occasionally affecting the perforator veins. Venous insufficiency and outflow difficulties are responsible for the development of venous hypertension and the emergence of clinical symptoms of chronic venous insufficiency.

Secondary changes usually result from deep thrombosis, but often the causative factor may be an injury leading to impaired venous flow and the development of clinical symptoms.

\section{Anatomical classification (A)}

The anatomical classification makes it possible to evaluate the extent of venous disease in relation to the anatomy of the venous system of the lower limbs. Consequently, it is necessary to determine whether pathological changes involve superficial, deep or perforator veins. It should be noted that the disease can affect only one or all systems at the same time.

$$
\begin{aligned}
& \text { Pathophysiological classification (P) } \\
& \text { Pr - reflux } \\
& \text { Po - obstruction } \\
& \text { Pr,o - reflux and obstruction } \\
& \text { Pn - no identification }
\end{aligned}
$$

CEAP classification is useful in clinical practice and suited for tracking the progression of the disease, however it is not recommended as a tool for monitoring the response to treatment $[16,17]$. The familiarity of dermatologists with the CEAP will be definitely beneficial in making diagnostic and therapeutic decisions, and will also enable dialogue with physicians of other medical specialties, particularly vascular surgeons.

\section{CLINICAL FEATURES OF SKIN LESIONS}

The clinical picture of chronic venous insufficiency is varied, ranging from telangiectasias, edema, reticular veins and skin fibrosis, to varicose veins and ultimately venous ulcers. All these manifestations are usually accompanied by pain in the lower limbs, especially after a longer period of standing, cramps and the feeling of "heavy legs". Skin pigmentation associated with hemosiderin accumulation as well as eczema-type lesions are seen as well. Also observed is the process of fibrosis in the skin and subcutaneous tissue (lipodermatosclerosis), and an increased risk of developing inflammation of the subcutaneous tissue (cellulitis), lower leg ulcers and impaired wound healing. The pronounced process ultimately leads to disorders of the lymphatic system and the development of chronic lymphedema.
pla-Trenaunaya, zespół Parkesa-Webera i wrodzone malformacje żylne. Zmiany pierwotne są przyczyną niewydolności układu żylnego, najczęściej występują w miejscu połączenia układu powierzchniowego z głębokim, niekiedy dotyczą żył przeszywających. Niewydolność i utrudniony odpływ odpowiadają za rozwój nadciśnienia żylnego i powstawanie klinicznych objawów przewlekłej niewydolności żylnej.

Zmiany wtórne są najczęściej wynikiem zakrzepicy głębokiej, często jednak czynnikiem sprawczym może być uraz, który prowadzi do utrudnienia przepływu żylnego i rozwoju objawów klinicznych.

Klasyfikacja anatomiczna (A)

Klasyfikacja anatomiczna umożliwia określenie zakresu choroby żylnej w odniesieniu do anatomii układu żylnego kończyn dolnych. Konieczne jest stwierdzenie, czy zmiany patologiczne dotyczą żył powierzchownych, głębokich czy przeszywających. Należy pamiętać, że choroba może dotyczyć tylko jednego lub wszystkich układów.

$$
\begin{aligned}
& \text { Klasyfikacja patofizjologiczna }(P) \\
& \text { Pr - refluks } \\
& \text { Po - niedrożność żył } \\
& \text { Pr,o - refluks i zaburzenia drożności } \\
& \text { Pn - brak identyfikacji }
\end{aligned}
$$

Stosowanie w praktyce klinicznej klasyfikacji CEAP jest przydatne i umożliwia monitorowanie postępu choroby, ale nie jest ona rekomendowana jako narzędzie do kontrolowania odpowiedzi na leczenie $[16,17]$. Znajomość klasyfikacji CEAP przez dermatologów będzie przydatna przy podejmowaniu decyzji diagnostyczno-terapeutycznych, ale także umożliwi prowadzenie dialogu z lekarzami innych specjalności, zwłaszcza z chirurgami naczyniowymi.

\section{OBRAZ KLINICZNY ZMIAN SKÓRNYCH}

Obraz kliniczny przewlekłej niewydolności żylnej jest różnorodny - obejmuje teleangiektazje, obrzęk, żyły siateczkowate, włóknienie skóry, żylaki i owrzodzenia żylne. Wszystkim tym zmianom zazwyczaj towarzyszy ból kończyn dolnych, zwłaszcza po dłuższym okresie stania, skurcze i uczucie ciężkości nóg. Występują również przebarwienia skóry związane z odkładaniem się hemosyderyny i zmiany wypryskowe. Obserwuje się proces włóknienia w skórze i tkance podskórnej (lipodermatosclerosis), zwiększa się ryzyko zapalenia tkanki podskórnej (cellulitis), owrzodzeń podudzi i upośledzenia gojenia się ran. Nasilony proces prowadzi do zaburzeń w układzie chłonnym i utrwalonego obrzęku limfatycznego. 


\section{Telangiectasias}

Telangiectasias are small dilatations of the subpapillary venous plexus, measuring up to $1 \mathrm{~mm}$ in diameter, which receive blood flowing back from venules or varicose veins. Telangiectasias may appear as discrete vessels or in clusters, and they are frequently symmetrical. They often occur around the medial malleoli. Larger lesions, dark blue in color, can be palpable, and the smallest lesions, occurring mainly in women, resemble a pale pink mesh. Telangiectasias may indicate disorders of the deep vein system, so they are considered as a cutaneous marker for the presence of this pathology. Even though they are initially considered as a cosmetic defect, they cannot be ignored, and in some cases they may also result in pain.

\section{Edema}

Chronic venous insufficiency is believed to be responsible for over $90 \%$ of all forms of lower limb edema. Edema of the lower limbs is one of the earliest symptoms of microangiopathy. The presence of this symptom nearly always indicates chronic venous insufficiency, and very often it accompanies other clinical manifestations such as varicose veins, leg pain and ulcers. Characteristically, edema is accompanied by pain and secondary development of trophic lesions which results from the presence of microangiopathy. Prolonged edema acquires a chronic course. The accumulation of fluid within the extracellular matrix produces, among other effects, changes in proteoglycans and the formation of voids, which in turn promotes an increase in fluid evacuation from the inside of vessels, ultimately leading to more pronounced edema [18].

\section{Varicose veins}

The most commonly observed types include reticular varicose veins and main trunk and collateral varicose veins. According to the literature, the problem affects $26-38 \%$ of women and $10-20 \%$ of men [19]. Usually, the first symptoms are already present in adolescents. According to the Bochum study the first lesions occur as early as between 10 and 12 years of age, and their incidence rises with age. Venous valve insufficiency plays a leading pathogenic role here, with venous reflux preceding the development of pathological lesions [18].

Venous valve insufficiency may be congenital or acquired [20]. Acquired insufficiency is most likely a result of inflammation and formation of an infiltrate consisting of monocytes and mast cells [21, 22]. Bergan et al. [23] highlight the key role of inflammation as the basic mechanism responsible for the progression of the disease and its symptoms. The first targets of the disease process are venous valves, where an inflammato-

\section{Teleangiektazje}

Teleangiektazje to drobne, wewnątrzskórne rozszerzenia splotu żylnego podbrodawkowatego o średnicy do $1 \mathrm{~mm}$, przyjmujące krew cofającą się z żyłek lub żylaków. Teleangiektazje mogą być pojedyncze lub występować w skupiskach, często są symetryczne. Zwykle występują wokół kostek przyśrodkowych. Większe zmiany o barwie ciemnoniebieskiej mogą być wyczuwalne palpacyjnie, natomiast zmiany najmniejsze, występujące głównie u kobiet, przypominają bladoróżową sieć. Obecność teleangiektazji może wskazywać na zaburzenia w układzie żył głębokich, więc uznaje się je niejako za skórny marker obecności tej patologii. Mimo że początkowo są one traktowane jako defekt kosmetyczny, nie można ich lekceważyć. W niektórych przypadkach mogą też powodować dolegliwości bólowe.

\section{Obrzęk}

Uznaje się, że przewlekła niewydolność żylna odpowiada za ponad $90 \%$ wszystkich postaci obrzęków kończyn dolnych. Obrzęk kończyn dolnych jest jednym z pierwszych objawów mikroangiopatii. Prawie zawsze świadczy on o przewlekłej niewydolności żylnej, bardzo często towarzyszy innym manifestacjom klinicznym, takim jak żylaki, bolesność nóg, owrzodzenia. Charakterystyczny jest towarzyszący ból i wtórny rozwój zmian troficznych, co wynika z mikroangiopatii. Długie utrzymywanie się obrzęku prowadzi do jego utrwalenia. Gromadzenie płynu w macierzy zewnątrzkomórkowej jest przyczyną m.in. zmian w obrębie proteoglikanów i powstawania wolnych przestrzeni, co z kolei sprzyja zwiększonej ucieczce płynu z wnętrza naczynia i prowadzi do nasilenia obrzęków [18].

\section{Żylaki}

Najczęściej obserwuje się żylaki siatkowate, żylaki głównych pni żylnych oraz żylaki naczyń pobocznych. Problem ten według piśmiennictwa dotyczy 26-38\% kobiet i 10-20\% mężczyzn [19]. Pierwsze objawy widoczne są zazwyczaj już u młodzieży. Zgodnie z opracowaniem „Bochum study” pierwsze zmiany pojawiają się nawet między 10. a 12. rokiem życia i częstość ich występowania zwiększa się z wiekiem. Niewydolność zastawek żylnych odgrywa główną rolę patogenetyczną, a refluks żylny wyprzedza pojawienie się zmian chorobowych [18].

Niewydolność zastawek żylnych może być wrodzona lub nabyta [20]. Nabyta niewydolność jest najprawdopodobniej wynikiem zapalenia i powstawania nacieku złożonego z monocytów oraz komórek tucznych [21, 22]. Bergan i wsp. [23] zwracają uwage na istotną rolę zapalenia jako podstawowego mechanizmu odpowiedzialnego za postęp choroby i wy- 
ry reaction has been demonstrated, with infiltrates of monocytes and macrophages identified on the valve cusps. Inflammation results in the remodeling of the valves which leads to their damage and venous hypertension. Hypertension triggers an interaction between leukocytes and venous endothelium, intensifying inflammatory processes, which closes the feedback loop of venous insufficiency [24]. Molecular research findings suggest that the inflammatory process also contributes to the remodeling of venous walls and promotes the formation of varicose veins. An increased amount of collagen and components of the extracellular matrix is observed in the vascular wall, which is associated with the disturbance of the ratio of mataloproteinases to their tissue inhibitors, in favor of the latter [24]. Another characteristic observation is an increase in the expression of TGF- $\beta 1$ (transforming growth factor- $\beta 1$ ) and bFGF (basic fibroblast growth factor) in the walls of varicose veins, which in turn promotes an increase in the synthesis of collagen and elastin [25].

Reticular varicose veins have diameters in the range of 1-4 $\mathrm{mm}$. They are located in the subcutaneous tissue, forming a mesh pattern. They are most commonly seen in the popliteal fossae and on the lateral surfaces of the lower limbs, and often connect to telangiectasia networks. They play an important role in hemodynamic disorders and may be the underlying cause of ulcer development.

The main trunk varicose veins are often observed unilaterally, and have diameters over $4 \mathrm{~mm}$ in the standing position. They usually involve the great saphenous vein and/or the small saphenous vein. Collateral varicose veins develop in the tributaries to the great saphenous and small saphenous veins and within their junctions.

\section{CUTANEOUS COMPLICATIONS}

An increase in venous pressure produces abnormalities in the skin and subcutaneous tissue, typically localized in the lower third of the shin. Acute complications include purpura, eczema, infectious lesions, dermatitis and cellulitis. Purpura results from increased blood vessel permeability due to elevated venous pressure, which leads to the extravasation of red blood cells. Exercise-induced purpura is often observed after physical activity at high ambient temperatures. The lesions affect mainly the lower legs, and the histopathological findings show leukocytoclastic vasculitis. The differential diagnosis should include thrombocytopenia, vasculitis and autoimmune diseases.

\section{Eczema-type lesions}

Eczema-type lesions can present as contact or stasis dermatitis. Contact dermatitis is more common stępowanie jej objawów. Pierwszym celem procesu chorobowego są zastawki żylne, gdzie potwierdzono obecność reakcji zapalnej, odnajdując nacieki monocytów i makrofagów na ich płatkach. Skutkiem zapalenia jest przebudowa zastawek, co prowadzi do ich uszkodzenia i wygenerowania nadciśnienia żylnego. Nadciśnienie wyzwala interakcję między leukocytami a śródbłonkiem żylnym, potęgując procesy zapalne, co zamyka pętlę sprzężenia zwrotnego patologii w niewydolności żylnej [24]. Wyniki badań molekularnych sugerują, że proces zapalny przyczynia się również do przebudowy (remodelingu) ścian naczyń żylnych i sprzyja powstawaniu żylaków. W ścianie naczyń obserwuje się zwiększoną ilość kolagenu i składowych macierzy zewnątrzkomórkowej, co wiąże się z zaburzeniem stosunku metaloproteinaz do ich tkankowych inhibitorów, na korzyść tych ostatnich [24]. Charakterystyczna jest też zwiększona ekspresja czynnika TGF- $\beta 1$ (transforming growth factor- $\beta 1$ ) oraz bFGF (basic fibroblast growth factor) w ścianach żylaków, co sprzyja nasileniu syntezy kolagenu i elastyny [25].

Żylaki siatkowate mają średnicę 1-4 mm, znajdują się w tkance podskórnej i mają wygląd siatki. Najczęściej obserwuje się je w dołach podkolanowych oraz na powierzchniach bocznych kończyn dolnych. Często zaopatrują sieci teleangiektazji. Odgrywają one istotną rolę $\mathrm{w}$ zaburzeniach hemodynamicznych i mogą być przyczyną rozwoju owrzodzeń.

Żylaki głównych pni żylnych często występują jednostronnie, a w pozycji stojącej mają średnicę powyżej $4 \mathrm{~mm}$. Zazwyczaj dotyczą żyły odpiszczelowej i/lub odstrzałkowej. Żylaki naczyń pobocznych rozwijają się w dopływach żyły odpiszczelowej i odstrzałkowej oraz w obrębie zespoleń pomiędzy nimi.

\section{POWIKŁANIA SKÓRNE}

W wyniku wzrostu ciśnienia żylnego dochodzi do zaburzeń w obrębie skóry i tkanki podskórnej, lokalizujących się najczęściej w 1/3 dolnej goleni. Do ostrych powikłań zalicza się: plamicę, zmiany wypryskowe, infekcyjne, zapalenie skóry i tkanki podskórnej. Plamica jest skutkiem zwiększenia przepuszczalności naczyń w wyniku podwyższonego ciśnienia żylnego, co prowadzi do wynaczynienia erytrocytów. Często obserwuje się plamicę związaną z wysiłkiem fizycznym przy wysokiej temperaturze otoczenia. Zmiany te występują głównie na podudziach, a w obrazie histopatologicznym stwierdza się leukocytoklastyczne zapalenie naczyń. W rozpoznaniu różnicowym trzeba pamiętać o małopłytkowości, zapaleniu naczyń oraz chorobach autoimmunologicznych.

\section{Zmiany wypryskowe}

Zmiany wypryskowe mogą mieć charakter kontaktowego lub zastoinowego zapalenia skóry. Kon- 
in patients with ulcers, and it is associated with the application of numerous topical preparations with allergenic potential. Other factors increasing the risk of allergy in this group of patients include damage to the epidermal barrier, chronic inflammation and long-term course. The most important contact allergens are: Balsam of Peru, fragrances, lanolin, rosin and neomycin. Therefore, to reduce iatrogenic contact sensitization, the use of preparations containing the above allergens should be limited [26].

\section{Stasis dermatitis}

A characteristic feature of chronic venous insufficiency is stasis dermatitis, hence in the majority of cases eczema-type lesions are accompanied by other manifestations including varicose veins, edema, lipodermatosclerosis, hemosiderin deposits and lower leg ulcers [27]. Clinical trials have shown that venous hypertension and inflammation are sufficient factors to induce inflammatory changes in the skin which resolve completely within a few weeks after surgical intervention removing the causes of venous hypertension. Inflammatory cells (including macrophages) accumulating around the wall of the venous vessel with an increased pressure produce, among others, metalloproteinases. Biopsy specimens taken from stasis dermatitis have shown a high level of expression of these proteins and low expression of their tissue inhibitors [28-30]. Most likely, the process induces damage to the extracellular matrix and impaired healing.

Clinically, stasis dermatitis is characterized by well-defined erythematous-desquamative lesions located on the lower legs, and accompanied by pruritus and lichenification. Pigmentation due to the deposition of hemosiderin is observed in the surrounding areas. Patients typically present with pain and leg cramps. Other reported symptoms include edema and foci of lipodermatosclerosis. In rare cases of untreated lesions, especially in the elderly, acroangiodermatitis (pseudo-Kaposi's sarcoma) may develop. Such cases require a skin biopsy [31-34].

It is also important to note the frequent co-occurrence of allergic contact dermatitis resulting from intensive topical treatment with drugs containing haptens with known potential sensitizing effects (e.g. antibiotics, Balsam of Peru, nickel, cobalt and preservatives), with a greater propensity to develop allergic reactions under conditions of chronic inflammation and accumulation of Langerhans cells in the epidermis. Patients frequently present with positive patch test results to antibiotics, so the topical use of such drugs is not indicated [35].

Elevated venous and lymphatic pressure also promotes the development of infections. Folliculitis, lichenification and erysipelas are observed in some taktowe zapalenie częściej występuje u chorych z owrzodzeniami i wiąże się ze stosowaniem licznych preparatów miejscowych mających zdolność do alergizacji. Czynnikami zwiększającymi ryzyko uczulenia w tej grupie pacjentów są uszkodzenie bariery naskórkowej, przewlekły stan zapalny oraz wieloletni przebieg choroby. Do najistotniejszych alergenów kontaktowych należą: balsam peruwiański, substancje zapachowe, lanolina, kalafonia i neomycyna. W celu ograniczenia jatrogennego uczulenia kontaktowego należy ograniczyć stosowanie preparatów zawierających wspomniane alergeny [26].

\section{Wyprysk zastoinowy}

Swoiste dla przewlekłej niewydolności żylnej jest występowanie wyprysku zastoinowego, tzw. stasis dermatitis, dlatego w większości przypadków zmianom wypryskowym towarzyszą inne objawy, takie jak żylaki, obrzęki, lipodermatoskleroza, złogi hemosyderyny i owrzodzenia podudzi [27]. W badaniach klinicznych wykazano, że nadciśnienie żylne oraz zapalenie są czynnikami wystarczającymi do wywołania zmian zapalnych skóry, które cofają się całkowicie w ciągu kilku tygodni po interwencji chirurgicznej usuwającej przyczyny nadciśnienia żylnego. Komórki zapalne, np. makrofagi, gromadzące się wokół ściany naczynia żylnego, w którym jest podwyższone ciśnienie, produkują m.in. metaloproteinazy. W wycinkach pobranych ze zmian w postaci wyprysku zastoinowego stwierdzono wysoką ekspresję tych białek i niską ekspresję ich tkankowych inhibitorów [28-30]. Najprawdopodobniej to zjawisko odpowiada za uszkodzenie macierzy zewnątrzkomórkowej i upośledzenie gojenia.

Klinicznie wyprysk zastoinowy charakteryzuje się dobrze odgraniczonymi zmianami rumieniowo-złuszczającymi zlokalizowanymi na podudziach. Zmianom towarzyszy świąd oraz lichenifikacja. W otoczeniu widoczne są przebarwienia wynikające z odkładania się złogów hemosyderyny. Pacjenci często zgłaszają bolesność i skurcze nóg, występuje też $\mathrm{u}$ nich obrzęk i ogniska lipodermatosklerozy. W rzadkich przypadkach nieleczonego wyprysku zastoinowego, zwłaszcza u osób starszych, mogą pojawić się zmiany o charakterze acroangiodermatitis (pseudomięsak Kaposiego). W takich sytuacjach konieczne jest wykonanie biopsji skóry [31-34].

Należy ponadto pamiętać o częstym współwystępowaniu alergicznego wyprysku kontaktowego, co wynika z intensywnego leczenia miejscowego lekami zawierającymi hapteny o znanym działaniu potencjalnie uczulającym (np. antybiotyki, balsam peruwiański, nikiel, kobalt i konserwanty) przy większej gotowości do reakcji alergicznych w warunkach przewlekłego stanu zapalnego i nagromadzenia komórek Langerhansa w naskórku. U chorych można też często stwierdzić dodatnie wyniki testów płatkowych 
patients. Very rarely, necrotizing fasciitis may also occur.

Late cutaneous complications of chronic venous insufficiency include skin hemosiderosis, trophic lesions, lymphatic vessel damage and lipodermatosclerosis, calcifications, atrophie blanche and shin ulcers. One of the studies has shown that the late cutaneous complications of chronic venous insufficiency occur in $9.6 \%$ of women and $8.7 \%$ of men [19]. Their incidence increases with the age of patients.

Despite a number of ongoing studies, the cause of skin lesions of this type has not been clearly established, however an important role is attributed to the so-called "leukocyte trapping". In patients with chronic venous insufficiency leukocytes have the ability to accumulate in the vessels of the lower limbs and adhere to the endothelium which then undergoes activation and, consequently, results in local inflammation [36]. Another significant factor is progressive skin fibrosis [37-39].

\section{Hemosiderosis}

Cutaneous hemosiderosis results from the degradation of extravasated erythrocytes, hemosiderin deposition and stimulation of melanin production. Clinical observations include indistinctly marginated brown red patches observed predominantly on the distal parts of the shins. The lesions tend to regress as the venous circulation improves.

Changes in the lymphatic circulation accompanying chronic venous insufficiency lead to the formation of lymphedema and elephantiasis.

\section{Lipodermatosclerosis}

Lipodermatosclerosis is a medical condition presenting with irreversible lesions in the skin and subcutaneous tissue in the form of infiltration, induration and strong adhesion to the underlying layer. The disease may occur in flares characterized by inflammatory symptoms and pain. Molecular studies have shown that ferritin deposits and iron ions present in the skin activate and increase the expression of metalloproteinases and oxidative stress, and the processes promote further tissue damage [30].

\section{Atrophie blanche}

Occasionally patients with chronic venous insufficiency also present with subcutaneous calcifications within the area of adipose tissue necrosis. Atrophie blanche is most commonly seen in women in the region of the medial malleolus or on the dorsal surface of the foot. Clinically, the condition is characterized by the presence of a patch of hardened skin, varying in size, porcelain-white in color, indistinctly demarcated from the surrounding area and z antybiotykami, dlatego ich stosowanie miejscowe nie jest wskazane [35].

Podwyższone ciśnienie żylne i limfatyczne sprzyja również rozwojowi zakażeń. U części pacjentów obserwuje się zapalenie mieszków włosowych, zliszajcowacenie, różę. Bardzo rzadko może też wystąpić martwicze zapalenie powięzi.

Do późnych powikłań skórnych przewlekłej niewydolności żylnej zalicza się: hemosyderozę skórną, zmiany troficzne, uszkodzenie naczyń limfatycznych i stwardniające zapalenie tkanki podskórnej (lipodermatosclerosis), zwapnienia, zanik biały (atrophie blanche) i owrzodzenia goleni. $W$ jednym $z$ badań późne powikłania skórne przewlekłej niewydolności żylnej stwierdzono u 9,6\% kobiet i 8,7\% mężczyzn [19]. Częstość ich występowania wzrasta z wiekiem pacjentów.

Mimo wielu trwających badań nie określono jednoznacznie przyczyny powstawania tego typu zmian skórnych, ale dużą wagę przywiązuje się do zjawiska tzw. pułapki leukocytarnej. Leukocyty u chorych na przewlekłą niewydolność żylną mają zdolność do gromadzenia się w naczyniach kończyn dolnych i przylegania do śródbłonka, który następnie ulega aktywacji. W konsekwencji dochodzi do powstania miejscowego stanu zapalnego [36]. Drugim czynnikiem jest postępujące włóknienie skóry [37-39].

\section{Hemosyderoza}

Hemosyderoza skórna jest skutkiem degradacji wynaczynionych erytrocytów, powstawania złogów hemosyderyny i stymulowania produkcji melaniny. Klinicznie obserwuje się brunatnoczerwone plamy o nieostrych granicach, szczególnie w dystalnych częściach goleni. Zmiany mają tendencję do wycofywania się wraz z poprawą warunków krążenia żylnego.

Zmiany w krążeniu limfatycznym towarzyszące przewlekłej niewydolności żylnej prowadzą do powstawania obrzęków limfatycznych i słoniowacizny.

\section{Lipodermatosclerosis}

Lipodermatosclerosis jest jednostką chorobową, w której powstają nieodwracalne zmiany w skórze i tkance podskórnej w postaci jej nacieczenia, stwardnienia i mocnego przylegania do podłoża. Choroba może przebiegać rzutami, w czasie których występują objawy zapalne i ból. W badaniach molekularnych wykazano, że obecne w skórze złogi ferrytyny i jony żelaza powodują aktywację i zwiększenie ekspresji metaloproteinaz oraz stresu oksydacyjnego, a zjawiska te sprzyjają dalszemu uszkodzeniu tkanek [30].

\section{Zanik biały}

Niekiedy u osób z przewlekłą niewydolnością żylną obserwuje się też podskórne zwapnienia w obszarze martwicy tkanki tłuszczowej. Zanik bia- 
slightly depressed. The lesion may be surrounded by hyperpigmentation or multiple telangiectasias. Small, painful and poorly healing ulcers may be seen in the middle.

\section{Ulcers}

Trophic ulcers are the most severe form of cutaneous manifestations of chronic cardiovascular insufficiency. They are typically located at $1 / 3$ of the distal medial surface of the lower legs in the ankle region. According to the definition, trophic ulcers involve the loss of the full thickness of the skin. Based on the CEAP classification, two stages can be differentiated: C5 - scar after healed ulcer and C6 - active ulcer. The lesions do not exhibit a tendency to heal spontaneously. Active lower leg ulcers affect about $0.3 \%$ of the adult population in Western European countries. They are more common in women and their incidence increases with age. The lesions can be discrete or multiple, of varying size, sometimes involving the whole circumference of the shin. Other symptoms of chronic venous insufficiency, including pigmentation or induration, are visible in the surrounding area. The ulcer usually penetrates down, without passing through the fascia, and can be filled with necrotic masses and fibrin, and contain serous or purulent exudate. During effective treatment, granulation tissue and islets of the epidermis appear at the base. Biopsy specimens should be taken from ulcers which take a long time to heal despite treatment in order to rule out the neoplastic process at the base of the ulcer.

\section{SYMPTOMS}

Symptoms are not specific to chronic venous insufficiency and may occur at all stages of the disease, from $\mathrm{C} 1$ to $\mathrm{C} 6$. A frequently reported symptom is edema and the feeling of swelling in the lower limbs, which is evidenced by knee sock and sock marks on the skin and occasionally even difficulties putting on shoes at the end of the day. In the mornings the symptoms are usually absent. Patients may also report lower extremity pain. It can take a variety of forms, from pain localized within the varicose vein or altered blood vessel, through diffuse pain particularly in the distal sections of the lower limbs, to intermittent claudication. In such cases, extensive differential diagnostics should be performed during the examination and taking the patient's medical history, with due consideration given to orthopedic, rheumatic and neurological causes of lower limb pain. Venous intermittent claudication should be differentiated with the arterial and neurogenic types. It is usually a consequence of iliac vein throm- ły najczęściej występuje u kobiet w okolicy kostki przyśrodkowej lub na grzbiecie stopy. Klinicznie ma postać różnej wielkości obszaru stwardniałej skóry, barwy porcelanowobiałej, niewyraźnie odgraniczonego od otoczenia, nieznacznie zagłębionego. Wokół zmiany może występować hiperpigmentacja lub liczne teleangiektazje. W centrum zmiany mogą się pojawić drobne, bolesne i trudno gojące się owrzodzenia.

\section{Owrzodzenia}

Owrzodzenia troficzne są najcięższymi skórnymi objawami przewlekłej niewydolności krążenia. Najczęściej lokalizują się w 1/3 dystalnej, przyśrodkowej powierzchni podudzi, w okolicy kostek. Zgodnie z definicją owrzodzenie jest ubytkiem pełnej grubości skóry. Klinicznie, zgodnie z klasyfikacją CEAP, wyróżnia się stadium C5 - obecność blizny po wygojonym owrzodzeniu i C6 - czynne owrzodzenie. Zmiany nie mają tendencji do samoistnego gojenia. Czynne owrzodzenia podudzi występują u ok. 0,3\% osób w populacji dorosłych w Europie Zachodniej, częściej u kobiet, a zapadalność wzrasta z wiekiem. Zmiany mogą być pojedyncze lub mnogie, różnej wielkości, niekiedy obejmują nawet cały obwód goleni. W otoczeniu owrzodzeń widoczne są inne objawy przewlekłej niewydolności żylnej, takie jak przebarwienia lub stwardnienia. Owrzodzenie zwykle drąży w głąb, nie przekraczając powięzi, może być wypełnione masami martwiczymi, włóknikiem oraz zawierać treść surowiczą lub ropną. W trakcie skutecznego leczenia w dnie pojawia się ziarnina i wysepki naskórka. W przypadku długo gojącego się owrzodzenia, mimo stosowanego leczenia, konieczne jest pobranie wycinka skóry w celu wykluczenia procesu nowotworowego w dnie owrzodzenia.

\section{DOLEGLIWOŚCI PODMIOTOWE}

Objawy podmiotowe nie są swoiste dla przewlekłej niewydolności żylnej, mogą pojawiać się we wszystkich stopniach zaawansowania choroby C1-C6. Często zgłaszanym objawem jest uczucie obrzęku i puchnięcie kończyn dolnych, o czym podczas badania świadczą ślady odciśniętych podkolanówek, skarpet. Niekiedy wieczorem pacjenci mają trudności z włożeniem obuwia. Rano dolegliwości te zazwyczaj nie występują. Pacjenci mogą również zgłaszać ból kończyn dolnych. Może on przyjmować różne postaci - dolegliwości bólowe w rzucie żylaka lub zmienionego naczynia, rozlany ból, szczególnie w dystalnych odcinkach kończyn dolnych, chromanie przestankowe. Podczas badania i zbierania wywiadu należy w tych przypadkach przeprowadzić szeroką diagnostykę różnicową, uwzględniając przyczyny ortopedyczne, reumatologiczne i neurologiczne dolegliwości. Żylne chromanie 
bosis and is characterized by pain experienced during walking by patients with detectable peripheral pulse and normal arterial pressure measured at the ankle. Pain resolves faster after elevating the legs than after stopping movement. Other symptoms reported by patients include the feeling of heavy legs, pruritus, night muscle cramps and the restless legs syndrome.

\section{CONFLICT OF INTEREST}

The authors declare no conflict of interest. przestankowe należy różnicować z tętniczym i neurogennym. Jest ono zazwyczaj wynikiem zakrzepicy żył biodrowych i charakteryzuje je ból podczas chodzenia u chorych, $\mathrm{u}$ których wyczuwalne jest tętno na obwodzie, a ciśnienie tętnicze na wysokości stawu skokowego jest prawidłowe. Ból ustępuje szybciej po uniesieniu nóg niż po zatrzymaniu się. Do kolejnych objawów zgłaszanych przez pacjentów należą uczucie ciężkości nóg, świąd, nocne skurcze mięśni i zespół niespokojnych nóg.

\section{KONFLIKT INTERESÓW}

Autorzy nie zgłaszają konfliktu interesów.

\section{References}

\section{Piśmiennictwo}

1. Jawień A., Szewczyk M.T., Kaszuba A., Gaciong Z., Krasiński Z., Wroński J., et al.: Wytyczne grupy ekspertów w sprawie gojenia owrzodzeń żylnych goleni. Leczenie Ran 2011, 8, 59-80.

2. Robertson L., Evans C., Fowkes F.G.: Epidemiology of chronić venous disease. Phelobology 2008, 23, 175-184.

3. Gloviczki P., Comerota A.J., Dalsing M., Eklof B.G., Gillespie D.L., Gloviczki M.L., et al.: The care of patients with varicose veins and associated chronic venous diseases: clinical practice guidelines of the Society for Vascular Surgery and American Venous Forum. J Vasc Surg 2011, 53, 2-48.

4. Smith J.J., Garratt A.M., Guest M., Greenhalgh R.M., Davies A.H.: Evaluating and improving health-related quality of life in patients with varicose veins. J Vasc Surg 1999, 30, 710-719.

5. Wittens C., Davies A.H., Bækgaard N., Broholm R., Cavezzi A., Chastanet S., et al.: Editor's Choice - Management of Chronic Venous Disease: Clinical Practice Guidelines of the European Society for Vascular Surgery (ESVS). Eur J Vasc Endovasc Surg 2015, 49, 678-737.

6. Evans C.J., Fowkes F.G., Ruckley C.V., Lee AJ.: Prevalence of varicose veins and chronic venous insufficiency in men and women in the general population: Edinburgh Vein Study. J Epidemiol Community Health 1999, 53, 149-153.

7. Jukkola T.M., Makivaara L.A., Luukkaala T., Hakama M., Laurikka J.: The effects of parity, oral contraceptive use and hormone replacement therapy on the incidence of varicose veins. J Obstet Gynaecol 2006, 26, 448-451.

8. Engelhorn C.A., Cassou M.F., Engelhorn A.L., Salles-Cunha S.X.: Does the number of pregnancies affect patterns of great saphenous vein reflux in women with varicose veins? Phlebology 2010, 25, 190-195.

9. Padberg Jr F., Cerveira J.J., Lal B.K., Pappas P.J., Varma S., Hobson R.W.: Does severe venous insufficiency have a different etiology in the morbidly obese? Is it venous? J Vasc Surg 2003, 37, 79-85.

10. Danielsson G., Eklof B., Grandinetti A., Kistner R.L.: The influence of obesity on chronic venous disease. Vasc Endovasc Surg 2002, 99, 271-276.

11. Zoller B., Ji J., Sundquist J., Sundquist K.: Family history and risk of hospital treatment for varicose veins in Sweden. Br J Surg 2012, 99, 948-953.

12. Krysa J., Jones G.T., van Rij A.M.: Evidence for a genetic role in varicose veins and chronic venous insufficiency. Phlebology 2012, 27, 329-335.

13. Bradbury A., Evans C., Allan P., Lee A., Ruckley C.V., Fowkes F.G.: What are the symptoms of varicose veins? Edinburgh vein study cross sectional population survey. Br Med J 1999, 318, 353-356.

14. Chiesa R., Marone E.M., Limoni C., Schaefer E., Petrini O.: Chronic venous insufficiency in Italy: the 24-cities cohort study. Eur J Vasc Endovasc Surg 2005, 30, 422-429.

15. Darvall K.A., Bate G.R., Adam D.J., Bradbury A.W.: Generic health-related quality of life is significantly worse in varicose vein patients with lower limb symptoms independent of CEAP clinical grade. Eur J Vasv Endovasc Surg 2012, 44, 341-344.

16. Eklof B., Rutherford R.B., Bergan J.J., Carpentier P.H., Gloviczki P., Kistner R.L., et al.: Revision of CEAP classification for chronic venous disorders: consensus statement. J Vasc Surg 2004, 40, 1248-1252.

17. Rabe E., Pannier F.: Clinical, aetiological, anatomical and pathological classification (CEAP): gold standard and limits. Phlebology 2012, 27, 114-118.

18. Nicolaides A.N.: Chronic venous disease and the leukocyte-endothelium interaction: from symptoms to ulceration. Angiology $2005,56,11-19$

19. International Task Force: The management of chronic venous disorders of the leg: an evidence-based report of an international task force. Phlebology 1999, 14 (Suppl 1), 23-34

20. Aravind B., Davies A.H.: Editorial. Phlebology 2004, 19, 55-56

21. Ono T., Bergan J.J., Schmid-Schönbein G.W., Takase S.: Monocyte infiltration into venous valves. J Vasc Surg 1998, 27, 158-166.

22. Yamada T., Tomita S., Mori M., Sasatomi E., Suenaga E., Itoh T.: Increased mast cell infiltration in varicose veins of the lower limbs: a possible role in the development of varices. Surgery 1996, 119, 494-497.

23. Bergan J.J., Schmid-Schonbein G.W., Coleridge-Smith P.D., Nicolaides A.N., Boisseau M.R., Eklof B.: Chronic venous disease. N Engl J Med 2006, 355, 488-498. 
24. Badier-Commander C., Verbeuren T., Lebard C., Michel J.B., Jacob M.P.: Increased TIMP/MMP ratio in varicose veins: a possible explanation for extracellular matrix accumulation. J Pathol 2000, 192, 105-112.

25. Badier-Commander C., Couvelard A., Henin D., Verbeuren T., Michel J.B., Jacob M.P.: Smooth muscle cell modulation and cytokine overproduction in varicose veins. An in situ study. J Pathol 2001, 193, 398-407.

26. Erfurt-Berger C., Geier J., Mahler V.: The current spectrum of contact sensitization in patients with chronic leg ulcers or stasis dermatitis - new data from the Information Network of Departments of Dermatology (IVDK). Contact Dermatitis 2017, 77, 151-158.

27. Sundaresan S., Migden M.R., Silapunt S.: Stasis dermatitis: pathophysiology, evaluation, and management. Am J Clin Dermatol 2017, 18, 383-390.

28. Jacob M.P., Badier-Commander C., Fontaine V., Benazzoug Y., Feldman L., Michel J.B.: Extracellular matrix remodeling in the vascular wall. Pathol Biol (Paris) 2001, 49, 326-332.

29. Herouy Y., Mellios P., Bandemir E., Dichmann S., Nockowski P., Schöpf E., et al.: Inflammation in stasis dermatitis upregulates MMP-1, MMP-2 and MMP-13 expression. J Dermatol Sci 2001, 25, 198-205.

30. Wenk J., Foitzik A., Achterberg V.: Selective pick-up of increased iron by deferoxamine-coupled cellulose abrogates the iron-driven induction of matrix-degrading metalloproteinase-1 and lipid peroxidation in human dermal fibroblasts in vitro: a new dressing concept. J Invest Dermatol 2001, 116, 833-839.

31. Collins L., Seraj S.: Diagnosis and treatment of venous ulcers. Am Fam Physician 2010, 81, $989-996$.

32. Palmer B., Xia Y., Cho S., Lewis F.S.: Acroangiodermatitis secondary to chronic venous insufficiency. Cutis 2010, 86, 239-240.

33. Lugovic L., Pusic J., Situm M., Buljan M., Bulat V., Sebetić K., et al.: Acroangiodermatitis (pseudo-Kaposi sarcoma): three case reports. Acta Dermatovenerol Croat 2007, 15, 152-157.

34. Yi J.U., Lee C.W.: Acroangiodermatitis. A clinical variant of stasis dermatitis. Int J Dermatol 1990, $29,515-516$.

35. Keller E.C., Tomecki K.J., Alraies M.C.: Distinguishing cellulitis from its mimics. Cleve Clin J Med 2012, 79, 547-552.

36. Thomas P.R., Nash G.B., Dormandy J.A.: White cell accumulation in dependent legs of patients with venous hypertension: a possible mechanism for trophic changes in the skin. BMJ 1988, 296, 1693-1695.

37. Vanscheidt W.Q., Kresse O., Hach-Wunderle V., Hasler K., Scharrer I., Wokalek H., et al.: Leg ulcer patients: no decreased fibrinolytic response but white cell trapping after venous occlusion of the upper limb. Phlebology 1992, 7, 92-96.

38. Takase S., Schmid-Schönbein G., Bergan J.J.: Leukocyte activation in patients with venous insufficiency. J Vasc Surg 1999, 30: 148-156.

39. Pappas P.J., You R., Rameshwar P., Gorti R., DeFouw D.O., Phillips C.K., et al.: Dermal tissue fibrosis in patients with chronic venous insufficiency is associated with increased transforming growth factor b1 gene expression and protein production. J Vasc Surg 1999, 30, 1129-1145.

Received: 14.03 .2018

Accepted: 10.06.2018

Otrzymano: $14.03 .2018 \mathrm{r}$

Zaakceptowano: 10.06.2018 r.

How to cite this article

Narbutt J., Bowszyc-Dmochowska M., Kapińska-Mrowiecka M., Kaszuba A., Krasowska D., Kręcisz B., Lesiak A., Lis-Święty A., Maj J., Nowicki R.J., Owczarek W., Placek W., Reich A., Rudnicka L.: Chronic venous insufficiency - epidemiology, classification and clinical picture. Diagnostic and therapeutic recommendations of the Polish Dermatological Society. Part I. Dermatol Rev/ Przegl Dermatol 2018, 105, 473-485. DOI: https://doi.org/10.5114/dr.2018.78069. 